\title{
Research on the Influence of Enterprise Social Responsibility on Financial Performance of Pharmaceutical Companies
}

\author{
Yu-rong Guan ${ }^{1, a}$, Kun-peng Zhou ${ }^{2, b,{ }^{*}}$ and Si-chen Zhou ${ }^{3, c}$ \\ ${ }^{1}$ Bohai university, 19 keji street, Jinzhou city, Liaoning province, China \\ ${ }^{2}$ Bohai university, 19 keji street, Jinzhou city, Liaoning province, China \\ ${ }^{3}$ Bohai university, 19 keji street, Jinzhou city, Liaoning province, China \\ a672762041@qq.com, bchow_ran@163.com, ${ }^{\mathrm{c}} 1021142276 @ q q . c o m$ \\ ${ }^{*}$ Corresponding author
}

\begin{abstract}
Keywords: Enterprise social responsibility, Financial performance, Externality, Pharmaceutical enterprise.
\end{abstract}

\begin{abstract}
The purpose of the enterprise is to pursue profits, and the enterprise social responsibility plays an important role in social development, so the fulfillment of enterprise social responsibility and the purpose of pursuing profits to a certain extent is contradictory. Especially, the social responsibility of pharmaceutical enterprises has a more significant impact on the society. Therefore, this paper takes the data of 160 pharmaceutical enterprises in A-shares in 2017 as samples and adopts multiple regression to analyze the impact of ESR on financial performance. It finds that the fulfillment of ESR has a negative effect on short-term financial performance and a positive effect on long-term financial performance.
\end{abstract}

\section{Introduction}

In order to avoid the generation of negative externalities, guide the healthy and sustainable development of enterprises, as early as 2006, China's "company law" clearly stipulated for the first time that "enterprises must assume social responsibility". With the adoption of international standards and systems (such as SA8000, ISO9000, ISO14000), it shows that government regulators have a clear attitude towards the need for enterprises to assume social responsibility. Enterprise financial goals is thought to be maximize Owner's equity, the common shareholders as the enterprise surplus right of owners, suggests the guarantee maximize shareholder rights and interests is to ensure that the premise of other stakeholder interests, among them, the enterprise social responsibility is the duty of the enterprise, is an important part of the other stakeholders. Therefore, the fulfillment of enterprise social responsibility will have an impact on the financial performance of the enterprise, and thus affect the financial objectives of the enterprise. As a special industry in society, medicine industry not only attaches importance to economic benefits, but also to social benefits. The balance between the pursuit of their own benefits and the degree to which they fulfill their social responsibilities will have a broad impact on the society. Due to the mandatory social responsibility, enterprises make a balance between the commitment of social responsibility and the growth of financial performance. However, in fact, whether the performance of enterprise social responsibility will harm the financial goal of maximizing shareholders' equity is yet to be determined. Therefore, this paper selected 160 pharmaceutical manufacturing listed companies in A-shares in 2017 to analyze the influence of overall social responsibility of pharmaceutical enterprises on financial performance by multiple regression, and further analyzed the relationship between them according to stakeholder theory.

\section{Theoretical analysis and research hypotheses}

In 1963, the Stanford research institution formally put forward the stakeholder theory. Its connotation is that all stakeholders of an enterprise have a multilateral contract relationship with each other, and the contract subject, namely the stakeholder, is the multi-party participant of the 
enterprise. So based on this theory, enterprise social responsibility can be divided into the social responsibility to shareholders, social responsibility to employees, social responsibility to the upstream and downstream enterprise and social responsibility to the environment, etc. The implementation of enterprise social responsibility will be to the enterprise financial goals and sustainable development ability to have a positive impact.

However, through empirical research on data of 451 listed companies in the UK in 2005 , Brammer et al. found that social responsibility was significantly negatively correlated with stock returns in current year ${ }^{[1]}$. Since stock returns in the current year are short-term indicators and reflect enterprise profits to a certain extent, enterprise social responsibility has a long-term impact. Therefore, enterprise social responsibility has a negative impact on enterprise short-term financial performance. By studying the data of A-shares listed companies in 2015, Wang Haibing et al. found that enterprise financial performance could promote the undertaking of social responsibility ${ }^{[2]}$. Yu Feng in 2016 to explore the transmission mechanism of enterprise social responsibility on financial performance. It is found that there is a positive relationship between enterprise social responsibility and enterprise financial performance ${ }^{[3]}$. This shows that when the enterprise meets the financial objectives of the current year, enterprise will focus on its social responsibility, and further improve the value of enterprises in the future. therefore, the social responsibility plays a positive role to enterprise's long-term financial performance. In 2011, based on the perspective of social capital, Hao Xiuqing drew the conclusion that the relationship between enterprise social responsibility and financial performance was uncertain ${ }^{[4]}$. To sum up, there is a correlation between ESR and financial performance, and ESR has a dual impact on enterprise performance.

In view of this, combined with the special status of pharmaceutical enterprises in society, this paper analyses the influence of overall social responsibility of pharmaceutical enterprises on long-term and short-term financial performance, and according to the stakeholder theory concretizes the overall social responsibility.

Therefore, this paper proposes the following hypotheses:

H1a: overall social responsibility of pharmaceutical companies has a negative effect on their short-term financial performance.

H1b: specific social responsibilities of pharmaceutical companies have a negative effect on their short-term financial performance.

$\mathrm{H} 2 \mathrm{a}$ : overall social responsibility of pharmaceutical enterprises has a positive effect on long-term financial performance;

$\mathrm{H} 2 \mathrm{~b}$ : specific social responsibilities of pharmaceutical enterprises have a positive effect on their long-term financial performance.

\section{Research design}

\subsection{Sample selection and data sources}

In order to ensure the completeness and accuracy of the data, the following selection was made by taking listed pharmaceutical companies in A-shares in 2017 as the research objects: (1) deleting ST and *ST company samples; (2) delete the company samples with abnormal financial data and defective indicators; (3) delete the samples of newly listed companies in 2017; (4) delete the sample of companies issuing B-shares and $\mathrm{H}$-shares at the same time. Finally, data of 160 sample enterprises were obtained. The data came from CSMAR database, HeXun net and the annual report of the enterprise. SPSS22.0 was used for quantitative analysis of the sample data.

\subsection{Variable selection and measurement}

\subsubsection{Explained variables}

Enterprise financial performance is divided into long-term performance and short-term performance. Since enterprise value is a comprehensive indicator reflecting the present and future value of enterprises, enterprise value multiple based on capital market is selected to measure the long-term financial performance of enterprises. As the core of Dupont analysis system, ROE is also a 
comprehensive index, but it only considers the short-term return of enterprises, so ROE is chosen to measure short-term financial performance.

\subsubsection{Explanatory variables}

This paper adopts the social responsibility report and professional evaluation system of listed companies published by independent third-party HeXun net to measure enterprise social responsibility. The data source is the social responsibility report and annual report issued by listed companies in A-shares. From the shareholders, employees, upstream and downstream enterprises, the environment to investigate social responsibility. Specific indicators are shown in table 1.

3.2.3 Control variables

A large number of research results show that the listing time and property nature of enterprises significantly affect financial performance. In order to avoid the influence of these variables on the empirical results, this paper selected enterprise size, enterprise listing time and enterprise property right nature as control variables. Specific variable indicators are defined in table 1.

Table 1 List of variable definitions

\begin{tabular}{|c|c|c|c|}
\hline variable types & variable name & symbol & variable to explain \\
\hline \multirow{4}{*}{$\begin{array}{l}\text { Explained } \\
\text { variables }\end{array}$} & Enterprise Value Multiple & EVM & Total market value/EBITDA \\
\hline & Return on equity & ROE & net profit/ Average balance of equity \\
\hline & $\begin{array}{l}\text { enterprise social } \\
\text { responsibility }\end{array}$ & ESR & $\mathrm{ESR}=\mathrm{SL}+\mathrm{ER}+\mathrm{UDCR}+\mathrm{EL}+\mathrm{SR}$ \\
\hline & Shareholders' liability & SL & $\begin{array}{l}\text { From the profit, debt repayment, return, letter of approval } \\
\text { and innovation five aspects of the summary consideration }\end{array}$ \\
\hline \multirow{5}{*}{$\begin{array}{l}\text { Explanatory } \\
\text { variables }\end{array}$} & Employees responsibility & ER & $\begin{array}{c}\text { Summarize employee performance, care for employees, } \\
\text { and safety }\end{array}$ \\
\hline & $\begin{array}{l}\text { Upstream and downstream } \\
\text { enterprise responsibility }\end{array}$ & UDCR & $\begin{array}{l}\text { From the product quality, after-sales service and integrity } \\
\text { reciprocity three aspects summary consideration }\end{array}$ \\
\hline & $\begin{array}{l}\text { Environmental } \\
\text { responsibility }\end{array}$ & EL & Consider from environmental governance \\
\hline & social responsibility & SR & From the value of the contribution to society \\
\hline & enterprise size & SIZE & The natural log of total assets at the end of the year \\
\hline \multirow{2}{*}{$\begin{array}{l}\text { Control } \\
\text { variables }\end{array}$} & enterprise listing time & TIME & The company have listed until 2018 \\
\hline & $\begin{array}{l}\text { enterprise property right } \\
\text { nature }\end{array}$ & OWNER & State-owned enterprises are 1 , otherwise 0 \\
\hline
\end{tabular}

\subsection{Model construction}

The model constructed in this paper is as follows:

$$
\begin{aligned}
& \mathrm{ROE}=\alpha_{0}+\alpha_{1} \mathrm{ESR}+\alpha_{2} \mathrm{SIZE}+\alpha_{3} \mathrm{TIME}+\alpha_{4} \mathrm{OWNER}+\varepsilon \\
& \mathrm{ROE}=\alpha_{0}+\alpha_{1} \mathrm{SL}+\alpha_{2} \mathrm{ER}+\alpha_{3} \mathrm{UDCR}+\alpha_{4} \mathrm{EL}+\alpha_{5} \mathrm{SR}+\alpha_{6} \mathrm{SIZE}+\alpha_{7} \mathrm{TIME}+\alpha_{8} \mathrm{OWNER}+\varepsilon \\
& \mathrm{EVM}=\alpha_{0}+\alpha_{1} \mathrm{ESR}+\alpha_{2} \mathrm{SIZE}+\alpha_{3} \mathrm{TIME}+\alpha_{4} \mathrm{OWNER}+\varepsilon \\
& \mathrm{EVM}=\alpha_{0}+\alpha_{1} \mathrm{SL}+\alpha_{2} \mathrm{ER}+\alpha_{3} \mathrm{UDCR}+\alpha_{4} \mathrm{EL}+\alpha_{5} \mathrm{SR}+\alpha_{6} \mathrm{SIZE}+\alpha_{7} \mathrm{TIME}+\alpha_{8} \mathrm{OWNER}+\varepsilon
\end{aligned}
$$

\section{Empirical analysis}

\subsection{Descriptive statistics}

The descriptive statistical results are shown in table 2. The mean EVM of the sample company is 62.95 and the standard deviation is 69.98 , indicating that there is a big difference in the long-term financial performance of pharmaceutical enterprises. The mean value of ROE was 0.11 and the standard deviation was 0.08 , indicating that the overall short-term financial performance of pharmaceutical enterprises had a small difference. The statistical results showed that the overall performance of social responsibility of pharmaceutical enterprises was uneven, for example, the mean ER was 1.77, RR was 1.08, and EL was 0.86. The average value of SL is 17.45 , but the standard deviation of SL is 6.23, indicating that the social responsibility of pharmaceutical enterprises to shareholders is unstable. In addition, the OWNER mean of 0.18 is caused by a non-state-owned pharmaceutical enterprise. The mean value of SIZE is 21.87 , and the standard 
deviation is 0.98 , indicating size difference is small. The mean TIME was 10.7 and the standard deviation was 6.79, indicating that the number of listed pharmaceutical enterprises was not centralized.

Table 2 descriptive statistics

\begin{tabular}{ccccc}
\hline Variables & MIN & MAX & Av. & Sd. \\
\hline EVM & 0.00 & 960.01 & 62.95 & 69.98 \\
ROE & 0.00 & 0.30 & 0.11 & 0.08 \\
ESR & -6.97 & 77.82 & 26.94 & 12.99 \\
SL & 0 & 26.69 & 17.45 & 6.23 \\
ER & 0 & 10 & 1.77 & 1.95 \\
RR & 0 & 20 & 1.08 & 4.24 \\
EL & 0 & 19 & 0.86 & 3.44 \\
SR & -7.31 & 12.39 & 5.76 & 2.88 \\
SIZE & 18.18 & 24.36 & 21.87 & 0.98 \\
TIME & 1 & 25 & 10.70 & 6.79 \\
OWNER & 0 & 1 & 0.18 & 0.38 \\
\hline
\end{tabular}

\subsection{Regression analysis}

Table 3 multiple regression of enterprise financial performance and social responsibility

\begin{tabular}{ccccccc}
\hline & \multicolumn{3}{c}{ Model 1a } & \multicolumn{3}{c}{ Model 2a } \\
\hline C & Beta & T-value & Sig. & Beta & T-value & Sig. \\
ESR & & 6.487 & .000 & & -.872 & .385 \\
SIZE & -.076 & -2.039 & .030 & .460 & 6.442 & .000 \\
TIME & -.463 & -6.01 & .000 & .087 & 1.167 & .245 \\
OWNER & .179 & 2.358 & .020 & -.187 & -2.53 & .012 \\
D-W & -.092 & -1.281 & .202 & -.001 & -.02 & .984 \\
\hline
\end{tabular}

As can be seen from the regression results in table 3, ESR of listed pharmaceutical enterprises is negatively correlated with ROE, the coefficient is -0.076 , which is significant at the level of $5 \%$. Its economic significance is that with the increase of social responsibility, ROE will fall, which verifies H1a hypothesis. Enterprise social responsibility has a positive relationship with EVM, the coefficient is 0.460 , which is significant at the $1 \%$ level. Its economic significance is that with the increase of social responsibility, the EVM will increase, which verifies hypothesis H2a. That is, the overall social responsibility of pharmaceutical manufacturing enterprises restricts the short-term financial performance of enterprises and promotes the long-term financial performance of enterprises. Further analysis is made on the different impacts of enterprise social responsibility on long-term and short-term financial performance (see table 4 for details).

Table 4 multiple regression of enterprise financial performance and specific social responsibility

\begin{tabular}{ccccccc}
\hline & \multicolumn{3}{c}{ Model 1b } & \multicolumn{3}{c}{ Model 2b } \\
\hline C & Beta & T-value & Sig. & Beta & T-value & Sig. \\
SL & & 6.259 & .000 & & -.138 & .890 \\
ER & -.173 & -2.088 & .038 & .837 & 14.832 & .000 \\
RR & .188 & 1.291 & .199 & .046 & .465 & .043 \\
EL & -.034 & -.123 & .902 & .055 & .292 & .771 \\
SR & -.078 & -.302 & .763 & .004 & -1.663 & .089 \\
SIZE & -.428 & -1.089 & .078 & .109 & 2.239 & .027 \\
TIME & .117 & 1.401 & .000 & -.062 & -1.159 & .248 \\
OWNER & -.095 & -1.309 & .163 & .1 & 1.768 & .079 \\
D-W & & 2.076 & & .051 & 1.036 & .302 \\
\hline
\end{tabular}

Table 4 regression results show that there are significant differences in the impact of five dimensions of specific social responsibility on long-term and short-term financial performance of 
pharmaceutical enterprises. Model $1 b$ shows that SL and SR coefficients of specific social responsibility of pharmaceutical enterprises are -0.173 and -0.078 respectively, and they are significant at the levels of $5 \%$ and $10 \%$ respectively. It shows that SL and SR have a negative impact on the short-term financial performance of enterprises. Verify hypothesis H1b. Model $2 b$ shows that SL, ER, EL and SR in the specific social responsibility of pharmaceutical enterprises are significantly positively correlated with the long-term financial performance of enterprises, which indicates that SL, ER, EL and SR have positive effects on the long-term financial performance of enterprises. Verify hypothesis H2b.

\section{Conclusion and revelation}

This paper analyzes the impact of ESR on the long-term and short-term financial performance of listed pharmaceutical companies in 2017.It is found that enterprise social responsibility has a negative effect on short-term financial performance and a positive effect on long-term financial performance. In the specific social responsibility of enterprises, the responsibility to shareholders and the responsibility to social contribution are the reasons for the decrease of short-term performance of enterprises, while the responsibility to shareholders、employees、 environment and social contribution is the reason for the improvement of long-term financial performance.

The purpose of the enterprise is to pursue profit, but the enterprise shall not serve as the embodiment of capital, only the pursuit of profit, the development of the society has produced enterprise, the enterprise shall also driving the development of society, to reduce the generation of negative externalities. Especially as a pharmaceutical enterprise, it should fulfill its social responsibility and reduce the social problems caused by negative externalities. In recent years, China has faced a serious problem that enterprises blindly pursue short-term profits, regardless of the negative impact on society, which also leads to the unsustainable development of their own. Therefore, regulatory authorities should guide enterprises to actively fulfill their social responsibilities by combining compulsory and non-compulsory means, which can not only make enterprises develop healthily and sustainably, but also benefit the development of the society.

\section{References}

[1] Brammer S, Millington A. Enterprise reputation and philanthropy: An empirical analysis[J]. Journal of Business Ethics, 2005, 61(1)

[2] Wang haibing et al. Influence of internal control and financial performance on enterprise social responsibility -- based on experience analysis of a-share listed companies [J]. Taxation and economics, 2015 (6).

[3] Yu feng. Impact of ESR on enterprise financial performance and its transmission mechanism [J]. Journal of shenzhen university: humanities and social sciences edition, 2016,33 (2)

[4] Hao xiuqing et al. Research on the impact of enterprise social performance on business performance from the perspective of social capital [J]. Science of science and technology management, 2011 (10). 